\title{
A espiritualidade da natureza A filosofia anteriana da natureza
}

\section{André Barata}

Com o presente artigo, o objectivo que prevemos alcançar é duplo. Por um lado, estará em causa expor a filosofia da natureza de Antero Quental, seu progressivo desenvolvimento no pensamento do autor açoreano, suas articulações no quadro de um todo cada vez mais sistemático que justifica e sustenta um elo de vida entre natureza e espírito. Por outro lado, em prol deste objectivo, importar-nos-á explicitar o alcance de algumas variações dentro do pensamento anteriano, isto sobre um núcleo invariante de noções, que adjectivaremos matricial, e que nos permitirá avaliar a unidade da sua Filosofia, justamente em torno da ideia de uma espiritualidade da natureza.

Neste quadro, tomaremos por objecto de análise, em quatro momentos, os seguintes textos de Antero de Quental: Espontaneidade (1866), Ensaio Sobre as Bases Filosóficas da Moral ou Filosofia da Liberdade (1874-75), Filosofia da Natureza dos Naturalistas (1886) e Tendências Gerais da Filosofia na Segunda Metade do Séc. XIX, cap. III (1890).

Em 1866, Antero de Quental publica, em $O$ Instituto, um artigo, que desde logo lança a noção de "espontaneidade" como uma das noções matriciais atrás referidas, e entre estas, a assinalar a sua importância, como ponto de partida, sempre retomado, ainda que não ultrapassando, neste escrito de juventude, os limites de um esboço, fixação de um quadro, a partir dos quais era previsível a necessidade de evolver no sentido de um aprofundamento, cuja última versão só estará patente, um quarto de século mais tarde, nas Tendências Gerais da Filosofia na Segunda Metade do Séc. $X I X$.

Dir-se-á, por outro lado, que em Espontaneidade se encontra o central da motivação que serve de impulso às obras ulteriores, exposta nesse escrito nos termos de uma preocupação que atinge o jovem Antero: no espírito do seu tempo sobrevive a ideia de uma cisão entre a alma humana e os "fundamentos do Universo". Mostrar o contrário, que uma tal cisão falseia e que o verdadeiro reside numa irmandade é o que este primeira reflexão de Antero visa alcançar'. E fá-lo precisamente através do que denomina "teoria da espontaneidade".

1 O artigo termina com as seguintes palavras: «Vê-se que a obra do homem tem por fundamento os mesmos fundamentos do Universo. A alma sente-se irmã no meio de todas as forças do mundo, e segue crente e confiada nos destinos comuns da familia universal. Isto basta para a segurança do espirito como para a paz do coração». ( Quental, Antero de, Obras Completas. Filosofia, (Organização, introdução e notas de Joel SERrño), Editorial Comunicação, 1989, Lisboa, p. 49) 
Esta teoria defende que o princípio responsável pelas criações do homem ao longo da História - a espontaneidade - está nele próprio, não lhe sendo, assim, transcendente. Trata-se, portanto, de um princípio imanente, o mesmo é dizer, de uma espontaneidade que confere ao homem a plena autoria e responsabilidade pela sua obra e que inscreve a liberdade no devir histórico. Uma tal espontaneidade erige-se em princípio ontológico do modo de ser humano, substituindo Deus, ou pelo menos um "Deus" em exterioridade para com o homem, pela humanidade ${ }^{2}$, em manifesto acordo com a célebre expressão de Vico "o homem é o seu mesmo criador"3.

Mas assim formulada, esta teoria da espontaneidade não basta para mostrar a irmandade profunda que deve, em tese, ligar a obra do homem e o Universo. Faltará, segundo Antero, mostrar como os fundamentos de uma e de outro são os mesmos. Esse passo complementar é cumprido por Renan, que Antero cita e subscreve, ao afirmar que:

«Sem dúvida o homem produz tudo o que sai da sua natureza. Concorre com a sua actividade; fornece a força bruta que produz o resultado. Mas a direcção dessa força não lhe pertence. Dá a matéria: a forma, porém, vem doutra parte. $\mathrm{O}$ verdadeiro autor das obras espontâneas é a natureza humana, ou, se se quiser, a causa superior da natureza. Neste ponto torna-se indiferente atribuir a causalidade a Deus ou ao Homem. $\mathrm{O}$ espontâneo é à uma humano e divino $)^{4}$.

Se Vico intuía a espontaneidade imanente às faculdades humanas, reconhecendo a sua autonomia, Renan, por seu turno, enraíza não tanto no homem mas, mais precisamente, na natureza humana essa espontaneidade. A diferença está em a natureza humana não se criar a si própria, contrariamente ao homem, o qual, por isso, é já resultado daquela. Neste sentido, a liberdade pensada por Vico iria muito mais longe do que a reflectida por Renan. Mas só pela consideração de uma natureza humana, fonte e não resultado de espontaneidade, Antero podia apresentar um termo comum a todo o universo e ao homem, em simultâneo: a natureza.

Optando, assim, por uma via em concordância com Renan, Antero, concluímos nós, não opta por substituir a transcendência pela imanência, mas antes por imanentizar a transcendência, sem a anular. Com efeito, há algo de transcendente no seio da própria imanência espontânea do homem, algo que é a da sua própria natureza e que, no limite, é o que orienta a sua existência. E essa transcendência, porque releva da natureza, não reside apenas no interior de cada homem; antes palpita em toda a realidade, orientando-a para um destino. É esta a tese de Antero de Quental, em que jamais deixará de insistir: "A alma sente-se irmã no meio de todas as forças do mundo, e segue crente e confiada nos destinos comuns da família universal"s.

Mas semelhante conclusão suscita mais interrogações do que soluções. Com efeito, se a espontaneidade humana reporta-se à sua própria natureza, e se esta se

2 «Deus cedeu a palavra ao homem. A humanidade tornou-se responsável pela sua obra. No fundo da grande e misteriosa página que se chama História, viu-se esta inesperada assinatura-liberdade». (Op. cit., p. 46)

3 O comentário de Joel Serrão parece-nos bastante certeiro: «Com efeito, A Bíblia da Humanidade de Michelet, Arte e Verdade-I. Carácter positivo da arte, Espontaneidade e O futuro da Música afiguram-se-nos como que rumos, afinal, convergentes, de uma mesma procura e problemática: a da des-transcendentalização do fenómeno humano considerado em si mesmo a partir da suas virtualidades imanentes. Ou seja, em palavras acaso mais claras: a busca da via explicativa da evolução humana tão-só a partir das virtualidades ou das «forças» implicadas nesse devir considerado de modo autónomo, em si e por si mesmo». (Op. cit., p. 190).

4 De l'Origine du Langage citado e traduzido por Antero de Quental (in Op. cit., p. 49).

5 Op. cit., ibidem. 
irmana num todo universal, então não será legítimo esperar que, de alguma forma, essa espontaneidade tenha uma expressão universal? E se a ideia de liberdade, por seu turno, foi claramente pensada em associação com a de espontaneidade, então como pode Antero esquivar-se ao paradoxo de uma realidade inconsciente mas livre? Ou dito doutro modo: em que é que a natureza humana se distingue das restantes forças do mundo natural? Em suma, como se harmoniza a intuição do que denominámos ser um elo vivo entre a "alma" e "as restantes forças do mundo", cuja consequência imediata é toda uma nova filosofia da natureza que carece de bases seguras, com a afirmação da especificidade do lugar do homem na natureza e na história? A estas questões só em 1890 Antero dará uma resposta mais ou menos definitiva, nas suas Tendências Gerais da Filosofia na Segunda Metade do Séc. XIX. No entanto, já antes, no Ensaio Sobre as Bases Filosóficas da Moral ou Filosofia da Liberdade, se começam a delinear os modos como obter as almejadas respostas ${ }^{6}$.

No Ensaio Sobre as Bases Filosóficas da Moral ou Filosofia da Liberdade escrito, avalia-se ${ }^{7}$, por volta dos anos de 1874-1875, Antero de Quental apresenta as bases essenciais para a constituição de uma filosofia da natureza - onde nos propõe, por meio do recurso à filosofia monadológica de Leibniz, uma explicação da matéria (e das forças que a animam), em acordo com a tese, defendida em Espontaneidade, de uma irmandade com a alma humana ${ }^{8}$. A monadologia, mais do que revelar a espiritualidade da matéria a Antero, vem confirmá-la, pois, na verdade, só espiritualizando a matéria seria sustentável a irmandade com a alma humana. Neste sentido, a monadologia leibniziana adaptada ao sistema em construção de Antero vale sobretudo como elemento que vem reforçar a intuição que se revelara já em Espontaneidade.

No entanto, o desenvolvimento desta concepção monadológica da matéria implica, além de uma espiritualização da matéria, a afirmação do atomismo. Cada mónada leibniziana, segundo o Antero do Ensaio, nada mais é do que um átomo, cujo carácter subjectivo consiste "na forma elementar e primordial da sensibilidade", que, por sua vez, "não é mais do que a forma elementar da representação". Ressurge assim, nestes átomos-mónadas, unidades básicas da matéria, uma espontaneidade imanente que os

6 Observamos, desde já, que não cabe no âmbito do presente artigo acompanhar as tentativas de resposta a todas estas questões, nomeadamente àquela que, porventura, foi a mais debatida na recepção do pensamento anteriano, a que se prende com o movimento de crescente aprofundamento da ideia de uma história universal, e com as etapas que Antero de Quental pretende descobrir no seu devir. Esse seria um outro trabalho que não aquele a que nos propusemos. No entanto, se frequentemente nos deparamos com o tema de uma história universal - que, nos termos de Espontaneidade, é a do próprio espírito - é simplesmente porque a sua raiz não está, para Antero, apenas no homem, mas em toda a natureza (de que o homem é apenas uma modalidade, embora justamente uma modalidade culminante), sem a qual não seria, pois, possível elucidar a sua filosofia da história. Esta observação mostrará grande relevância quando analisarmos a III Parte das Tendências. Entre filosofia do espírito e filosofia da natureza, embora necessariamente indissociáveis em Antero, interessa-nos a segunda, mas se há uma história do espírito é precisamente a da natureza, estando aquela para esta como um capítulo final para o todo da obra.

7 Só publicados postumamente, segundo investigação de Joaquim de Carvalho, «os fragmentos [do Ensaio] não estão datados, mas pela correlação com a carta (LXXXII) a João Lobo de Moura, dubitativamente, escrita em 1873, pode pensar-se serem de 1874-1875» (citado por Joel Serrão, Op. cit., p. 198).

8 Reportando-se ao Ensaio, Joel Serrão mede a importância deste recurso a Leibniz: «Em suma: Antero encontrara na metafísica de Leibniz (1646-1716) solução para o problema com o qual sempre se debatera, particularmente nessas bem complexas mónadas que seriam, a um mesmo tempo, de natureza material e espiritual (ou energética) e, sobretudo, são os verdadeiros Átomos da Natureza, e numa palavra os elementos das coisas» (Op. cit., p. XXIV). 
move por si próprios. Daí a afirmação anteriana de que "tudo se faz mecanicamente, menos o princípio do mecanismo", pois este limita-se a descrever como se conduz o movimento pela matéria sem poder indicar a origem e o fim desse movimento. Contra a ideia de que o movimento, de alguma forma, subsista continuamente, Antero afirma que "todo o movimento é provocado: nenhum movimento é comunicado"l0.

Note-se, todavia, que, segundo Antero, a percepção do movimento resulta de um estado relacional de átomos-mónadas; tal como o espaço e o tempo, são determinadas percepções de estados relacionais. Assim, diz-nos o autor, o movimento "não é, em si, alguma cousa: o que é alguma coisa são os estados diversos das mónadas e a relação desses estados" "11. Decorre deste nada ser do movimento que seja, no fim e ao cabo, uma ilusão. E é neste preciso ponto que se faz notar a segunda grande influência filosófica neste Ensaio, a do pensamento de Schopenhauer. O mundo da fenomenalidade, da mudança e do movimento anulam-se numa aparência que ilude um nível de ser aquém dessa realidade superficial, nível profundo do ser, onde à espontaneidade é dado um outro nome: vontade.

Estas considerações de tom schopenhaueriano acerca da natureza do movimento não subsistirão nos textos ulteriores, sobretudo pela razão simples de nestes Antero se afirmar um autor profundamente realista, não estando disposto a manter o carácter ilusório dos factos. O sinal mais claro da radical diferença que, neste aspecto, vai do Ensaio para A Filosofia da Natureza dos Naturalistas e para as Tendências está no modo como neste últimos textos Antero renega, de um ponto de vista epistemológico, a metodologia professada no anterior. Enquanto em A Filosofia da Natureza dos Naturalistas e nas Tendências é repetidamente enfatizado o papel do método indutivo na ciência e desta, por seu turno, como etapa para uma filosofia, no Ensaio um tal desempenho da ciência e da sua metodologia indutiva não tinha qualquer cabimento em virtude da desacreditação aí patente do movimento da natureza, ou seja, da ordem dos fenómenos ditos naturais. A diferença está, portanto, em a factualidade ser, nas Tendências e em A Filosofia da Natureza dos Naturalistas, o domínio sobre o qual se constrói todo o sistema anteriano, o que compromete a realidade dos factos pela sua estrita evidência no sentido cartesiano e a validade das induções que a ciência leva a cabo. No Ensaio, em suma, as induções da ciência nada valem para a filosofia porque os fenómenos da experiência sensível são, já de si, mera aparência ${ }^{12}$.

\section{III}

Antero de Quental foi contemporâneo do conflito entre o positivismo, na época em ascensão, e os grandes sistemas idealistas, então em declínio, e que no domínio das filosofias da natureza assumiu a configuração de uma' disputa entre dois pólos: metafísicos, por um lado, e naturalistas, por outro lado. É no âmbito deste conflito que surge o texto A Filosofia da Natureza dos Naturalistas, em março de 1886, como reacção directa à obra de um autor brasileiro Artur Viana de Lima, Exposé Sommaire des Théories Transformistes de Lamarck, Darwin et Haeckel, que havia sido publicada no início do mesmo ano $^{13}$.

Op. cit., p. 86.

Op. cit., p. 87.

Op. cit., ibidem.

2 Com efeito, lê-se no Ensaio, «a generalidade íntima e superior, na qual resida a lei ou razão primeira das cousas, só pode ser atingida pela pura especulação, pela análise das ideias em si, independentemente de quaisquer induções fundadas na experiência». (Op. cit., p. 80)

13 A mostrar a importância com que no Brasil o positivismo se impunha talvez não haja prova mais cabal do que a segunda constituição brasileira, aquando a transformação do Brasil em 
O intento fundamental de Antero consistiu aí em desfazer a aparente contradição entre materialismo e idealismo, em boa parte empolada, segundo o autor, pelos naturalistas de origem positivista, mas com responsabilidades também por parte de um idealismo contemporâneo avesso ao esclarecimento ${ }^{14}$.

Segundo Antero de Quental, o conhecimento pode estratificar-se em três níveis, que se obtêm na seguinte sequência: primeiramente, o nível das opiniões, que são a matéria que preenche, num segundo momento, a forma científica, e que consiste no nível da ciência; e, por fim, o nível da metafísica, forma cuja matéria será, por sua vez, os dados da ciência. Por conseguinte, nem se faz metafísica sem ciência ${ }^{15}$, nem se conhece cientificamente sem opiniões, conquanto o saber da ciência seja superior ao opinativo, e o metafísico superior a qualquer um dos outros, como o único saber efectivamente filosófico.

O segundo aspecto que importa referir é o de que, nessa estratificação de níveis de saber, os filósofos que se enquadram na corrente que Antero denomina filosofia da natureza dos naturalistas, nomeadamente o luso-brasileiro Viana, negam a importância do último desses níveis, o especulativo-metafísico. Afirmam eles que a ciência é o conhecimento por excelência, suficiente para dar a conhecer tudo aquilo que possa ser conhecido bem na esteira do ideário positivista da época. Ainda relativamente a esta posição, Antero ensaia uma explicação histórica: tratar-se-ia de um reacção ao

República em 1889. Só o facto da divisa nacional - "ordem e progresso" - ser justamente a de Auguste Compte reflecte como o espírito positivista dominava o Brasil nos fins do século.

14 Em carta a Jaime Batalha Reis, de 24 de Dezembro de 1885, Antero de Quental faz a síntese da sua solução para o conflito entre idealismo e materialismo - «[...] A dita minha filosofia não é original. É antes uma fusão (não amálgama) do Hegelianismo com a monadologia do Leibniz, dando de si a síntese do idealismo e do espiritualismo num terreno que à primeira vista se parece com o materialismo. Digo que se parece, porque o meu ponto de partida é com efeito o materialismo, ou atomismo científico. Mas reduzindo a ideia de átomo à de forca, e esta à de espírito, e transportando para o átomo-mónada toda a espontaneidade e virtualidade que o Hegel atribuiu à ideia, consigo reconduzir o Idealismo e o Espiritualismo da região vaga e abstracta por onde tem andado para um terreno, quanto é possível nestas coisas, poșitivo». (Obras Completas de Antero de Quental, Cartas II, Lisboa, 1989, carta 467, p. 762) É claro, por conseguinte, que Antero de Quental resolve a aparente contradição entre materialismo e idealismo, partindo de uma análise da noção de matéria, espiritualizando-a, e, por extensão, espiritualizando a natureza. Por outras palavras, é no materialismo que se encontrará a sede última do "espiritualismo renovado" proposto em Tendências.

15 Escreve Antero de Quental no quinto e último artigo de A Filosofia da Natureza dos Naturalistas: «Se uma filosofia positiva é e será sempre, como já mostrei, uma quimera, a acção e autoridade directa da ciência na filosofia será daqui em diante (quero dizer, depois da Crítica da Razão Pura) um facto que tem de se impor a todos os pensadores». (Op. cit., p. 110). A ciência e a sua autoridade não são, pois, indiferentes à filosofia. Mas, em manifesta crítica ao positivismo, que já vinha do tempo do Ensaio, não é possível pretender com legitimidade substituir a filosofia pela ciência, sequer limitar o filosofar a uma metodologia indutiva. Este posicionamento crítico face ao método indutivo, embora reconhecendo-lhe um desempenho que no Ensaio não reconhecia, pode bem ser articulado com os de um Gaston Bachelard ou de um Karl Popper, ambos epistemólogos que, tal qual Antero, mas já dentro do séc. XX, associaram à crítica ao indutivismo a justificação pertinente da especulação metafísica. Com efeito, não é de forma alguma estranha a formulações popperianas hoje em dia já clássicas, a seguinte afirmação de Antero: "Não cabe em escrito destas dimensões expor a teoria da hipótese. Bastará mostrar como a teoria geral da evolução, hoje com tanto vigor e brilho formulada por Haeckel e seus concorrentes ou discípulos, longe de ser, como vulgarmente se imagina, uma descoberta das ciências naturais e um resultado directo da análise científica, é, pelo contrário, uma verdadeira hipótese filosófica, que, produto da elaboração especulativa de perto de três séculos, acabou por se manifestar no domínio das ciências". (Op. cit., ibidem). Em todo o caso, convém deixar claro que Antero em momento algum da sua obra defende a invalidade do método indutivo. Aliás, reconhece essa validade, não só como parte integrante do fazer ciência, mas também, como se atesta nas Tendências, do próprio fazer filosofia. 
dogmatismo alemão e ao convencionalismo francês, por um lado, e de uma tendência, historicamente definida, para a unificação do conhecimento, por outro.

A escola que, contemporaneamente a Antero de Quental, melhor representava estes pensadores era a monista-evolucionista, tendo como expoente mais célebre Haeckel. Ora, será a esta escola, aquela na qual Viana de Lima se reconhece, que Antero criticará quatro noções, a saber, as de monismo, espontaneidade, evolução e finalidade.

No que respeita à noção de monismo, Antero denuncia dois falsos pressupostos que não permitem, por meio daquela noção, que se dilucide minimamente o problema do materialismo, como problema capital da filosofia da natureza. São eles o não-atomismo, por um lado, e a exclusão da análise das ideias de substância, forma e movimento, por outro. De acordo com Antero, o termo monismo nada refere a não ser a simples unidade da substância, pelo que sem um prévio esclarecimento do que quer que se entenda por substância, dificilmente se poderá esclarecer o que possa significar a noção de monismo para Haeckel. Não basta, pois, "afirmar abstractamente a unidade da substância [...]. O que importa é defini-la"16. Há que explicar como se passa das "omnímodas modalidades" à unidade da substância.

Já por outro lado, a argumentação monista entra, segundo Antero, em contradições insanáveis no seu esforço de evitar noções de cariz metafísico como a de substância. Em primeiro lugar, afirma-se ser grande erro destacar determinadas propriedades, em desfavor de outras, para definir matéria, argumentando-se desta forma contra uma concepção da matéria como atomismo. Contudo, num segundo momento já se destaca uma propriedade fundamental, o movimento, não obstante o argumento anterior. Assim, sem nenhuma justificação coerente, a não ser um salto especulativo encapotado, ou uma exorbitação da ciência, prefere-se um dinamismo a um atomismo ${ }^{17}$. Mas, questiona Antero de Quental, como se explica a diversidade, a descontinuidade e o próprio dinamismo sem se pressupor a existência de átomos? Como falar de conhecimento científico sem uma multiplicidade descontínua, quantificável e, portanto, numerável de átomos?

Estas incongruências revelam simplesmente que Haeckel e seus discípulos não levam a cabo uma verdadeira tentativa de filosofia de natureza e que não o fazem justamente por não reconhecerem a legitimidade de um abordagem especulativa, mesmo quando também a empregam, ainda que não o assumindo. Nas palavras de Antero de Quental:

«[...] e uma tentativa de filosofia da natureza só merecerá este nome quando sobre a análise das ideias de substância, força e movimento se assente uma doutrina da matéria, que satisfaça ao mesmo tempo às exigências puramente racionais da especulação e às mais práticas da indagação científica» ${ }^{18}$.

Quanto à noção monista-evolucionista de espontaneidade, Antero de Quental indica prontamente uma contradição: embora se afirme a ideia de uma espontaneidade

"Ora, o monismo, atribuindo ao ponto de vista das ciências físicas um carácter absoluto, arvorando as ideias gerais dum grupo de ciências em ideias últimas eirredutíveis, exorbitou da ciência sem ao mesmo tempo fazer acto de filosofia". (Op. cit., p. 101)

18

Op. cit., p. 99. Acerca deste ponto Leonardo Coimbra diz-nos o seguinte: «[...] monismo é um doutrina de contornos imprecisos e incapaz de explicar como a substância una e simples pode determinar-se em movimento e variedade. Os monistas protestam contra o atomismo, e, no entanto, ele impõe-se como um facto à sensação e como um postulado à ciência, para a possível determinação numérica». (Leonardo Coimbra, O Pensamento Filosófico de Antero de Quental, Porto, cap. I; citado por Joel Serrão, Op. cit., p. 211). 
da matéria em contraste com uma física da inércia ${ }^{19}$, tal afirmação não é compatível com a do princípio da conservação do movimento e da evolução como exclusivo resultado do puro mecanismo. A aporia dos naturalistas salta, pois, à vista - como conciliar uma dinâmica, assegurada pela espontaneidade, com o puro mecanismo, onde, saliente-se, o princípio dinâmico lhe é extrínseco? Assim, só se pode concluir que os pensadores naturalistas não compreenderam, embora a afirmem, a efectiva espontaneidade do real. Aliás, Antero aponta logo uma resposta à dificuldade: a formulação de uma hipótese metafísica, função que exorbita os limites e competências da ciência naturalista ${ }^{20}$.

A terceira noção é a ideia, central no pensamento de Haeckel, de uma evolução natural. Tal ideia de evolução, para os naturalistas, surge como síntese científica, isto é, como abstracção máxima dos dados que a ciência integra, e não como sistema filosófico desenvolvido pela especulação metafísica. Contudo, Antero de Quental descobre nessa ideia de evolução dos naturalistas, ao contrário do que estes suporiam, uma construção filosófica, ainda que não assumida, e, portanto, uma sistematicidade. E isto decorre da injustificabilidade dessa ideia de evolução a partir de bases rigorosamente científicas. Donde que aqui, e uma vez mais, haja um equívoco a explicitar: a ideia de evolução é ideia de um sistema, necessariamente especulativo, e considerá-la uma síntese estritamente científica só pode consistir numa "[...] extensão abusiva da indução científica e ilegítima generalização de uma hipótese $[\ldots]^{\prime 21}$.

Em último lugar, Antero pretende desfazer mais uma falácia dos naturalistas, os quais julgam, ao atacar com toda a justiça uma certa aproximação antropomórfica à ideia de finalidade, destruir toda e qualquer noção de finalidade, incluindo a noção metafísica de finalidade. Ao distinguir pelo menos estas duas concepções de finalidade, Antero anula formalmente a eficácia do argumento contra a noção de finalidade imanente, justamente a que lhe parece, desde os escritos de juventude, filosoficamente mais interessante. E reafirma a necessidade de uma tal noção, pois porque, primeiramente, $o$ movimento, per se, é irracional; dito doutro modo, a racionalidade do movimento implica algo que lhe é exterior, um desenvolvimento em direcção a um fim e, assim, uma finalidade. Em segundo lugar, e na medida em que é uma espécie de movimento, a evolução exige também ela uma finalidade; contudo, exige-a propriamente (e já não pela força exterior de uma racionalidade) porque, enquanto "hierarquia ou desenvolvimento"22, pressupõe, per se, a finalidade ${ }^{23}$. Por outras palavras, caracterizando a evolução como série e a finalidade como tipo, só se pode concluir por uma anterioridade lógica, mesmo ontológica,

19 É o seguinte o comentário de Leonardo Coimbra:

«A matéria é dotada de espontaneidade ou é inerte?

Igualmente a doutrina se apresenta aqui duvidosa e ambígua: afirma vagamente e no todo a espontaneidade, mas, por necessidades científicas, afirma a inércia em cada um e em todos os casos particulares ou sistemas parcelas do universo». (Op. cit., p. 211).

20 Para Antero de Quental, a especulação metafísica, que os naturalistas tanto repudiam, consiste, na prática, no trabalho de formulação de hipóteses filosóficas. Essas hipóteses transcendem os limites da conhecimento científico. Uma vez mais, é notória a rejeição de uma metodologia indutivo-dedutiva, perfilhando-se, bem diversamente, um pensamento, a um tempo, conjectural e metafísico como ponto de partida para uma filosofia da natureza.

21 Op. cit., p. 104.

22 Op. cit., p. 106.

23 O importante na relação e distinção entre movimento e evolução é que esta, enquanto espécie do género que é aquele, tem por diferença específica a característica de "hierarquia ou desenvolvimento", o que outra coisa não significa senão finalidade. De facto, Antero de Quental tomara o desenvolvimento como algo racionalmente imprescindível, conquanto não necessário, uma vez que per se nada o garantia. Esse desenvolvimento, por seu turno, comportava necessariamente um tipo e, consequentemente, uma finalidade. A evolução, por seu lado, toma justamente esse desenvolvimento (e consequente finalidade) como próprio à sua natureza. Assim, poder-se-ia dizer, na linha desta interpretação, que a existência da evolução é o garante da racionalidade do movimento. 
da finalidade face à própria evolução - "o tipo é realizado na série, não é um produto dela $[\ldots]^{\prime 24}$.

Ora, se a evolução implica a finalidade, como sustenta Antero, então a negação desta só pode significar, por um óbvio Modus Tollens, a negação daquela, o que refutaria o monismo-evolucionista por uma reductio ad absurdum. Dir-se-á, pois, que a evolução é um facto inquestionável e que, todavia, seria contraditório sustentar uma evolução que não dispusesse de uma teleologia imanente.

Após esta primeira parte de Filosofia da Natureza dos Naturalistas dedicada à análise e crítica das principais noções da escola monista-evolucionista, sucede-se uma segunda, que se propõe restituir à filosofia da natureza aquilo que os naturalistas the retiraram - a reflexão especulativa. Esse trabalho da especulação filosófica, como já se disse, concretiza-se pela formulação de hipóteses filosóficas que deverão ser escolhidas com base numa racionalidade. Num primeiro momento, a hipótese filosófica é a correspondente à noção de evolução, enquanto movimento teleológico e espontâneo.

Em última análise, segundo Antero de Quental, a compreensão total da razão é o idealismo, cumprindo a insuficiência do materialismo sem, porém, o negar, tendo-o, pelo contrário, como ponto de partida imprescindível. Não há verdade filosófica sem idealismo nem idealismo sem materialismo. Mas esta conclusão, note-se bem, deve ser alcançada em dois planos: por um raciocínio epistemológico, em que materialismo e idealismo são sobretudo termos que se reportam às áreas de saber científico e especulativo, respectivamente; mas igualmente pela afirmação ontológica de uma dupla instanciação do ser - "o movimento não esgota o ser: o ser implica movimento e ideia"25. Donde que, Antero possa justificar, por meio de uma ontologia (e já não tanto por uma epistemologia) várias dicotomias:

«Matéria e espírito, determinismo e liberdade, evolução e finalidade, não são ideias contraditórias senão na aparência: de facto são só duas esferas diferentes da compreensão, tese e antítese, cuja síntese é a razão» ${ }^{26}$.

Mas com isto não se quer deixar de realçar a pertinência da perspectiva epistemológica. Com efeito, há que apontar a referência anteriana à razão especulativa ou consciência ccmo um domínio especial da factualidade, aquilo a que chama "factos culminantes". Enquanto factos, por um lado, não podem ser ignorados, não devendo ser remetidos para uma esfera extra-factual, devendo, pelo contrário, ser ainda situados na realidade; e enquanto factos culminantes, por outro, afirmam-se como critério filosófico - ou seja, como base incontornável para um projecto filosófico totalizante ${ }^{27}$. Por outras palavras, se a consciência não é factualidade primeira na ordo essendi, é-o, todavia, na ordo cognoscendi.

Assim, o argumento de Antero de Quental, menos do que pedir explicações dos fenómenos complexos, consiste em expor a incapacidade do materialismo explicar, por si só, os fenómenos mais simples, como a mais elementar sensação - de certo modo, dir-se-ia, porque falham o ponto de partida adequado, a consciência. Essa incapacidade só é superável pelo idealismo (que integra de forma conciliadora o próprio materialismo), ou seguindo a designação que Antero perfilhará, pelo "novo espiritualismo".

Este esforço de Antero de Quental no sentido de elaborar uma síntese que unifique sistemas aparentemente antagónicos, se não mesmo contraditórios, confirmar-se-á no

27 Aliás, como teremos oportunidade de observar, nas Tendências Filosóficas serão estes mesmos factos culminantes, restabelecido o seu lugar na realidade e o seu estatuto prioritário, que permitirão a Antero a construção de uma filosofia, a um tempo, realista e indutivista. 
seu último escrito filosófico, as Tendências Gerais da Filosofia na Segunda Metade do Século XIX.

Contrariamente ao juízo que poderia passar acerca do cap. III das Tendências de que o seu tom marcadamente poético coarctar-lhe-ia a sua virtualidade filosófica ${ }^{28}$, a verdade é que Antero de Quental regista aqui um extensa argumentação que se desenvolve, na sua unidade, por meio de argumentos parcelares cuja articulação é suficientemente clara e rigorosa para dar expressão a um ambicioso, embora programático, sistema filosófico.

Com efeito, Tendências Gerais da Filosofia na Segunda Metade do Séc. XIX vai muito além do que o seu título porventura deixaria antecipar. Além da apresentação, nos seus traços essenciais, das tendências filosóficas que marcavam, então, o panorama da reflexão europeia, tendências que, segundo o autor, se podem organizar sob quatro correntes - o Positivismo, o Idealismo Alemão, o Espiritualismo e o Criticismo -, nesta obra Antero trata de explicitar as suas limitações respectivas e, consequentemente, mostrar como todas elas, sem excepção, revelam a mesma incapacidade para constituir um sistema completo. Mas a feitura deste trabalho, nas primeiras duas partes da obra, obedece a um desígnio mais ambicioso, a saber, determinar se entre estas tendências gerais da filosofia existe uma meta comum, uma mesma confluência, de forma a que se possa instaurar, entre elas, uma efectiva síntese filosófica ou se, pelo contrário, entre elas não se conseguirá alcançar mais do que uma amálgama sincrética.

A resposta a este desígnio em Tendências é a de que uma tal síntese é possível, no que se configura uma segunda grande tese anteriana ${ }^{29}$, ao lado da que afirma existir um elo de vida, a mesma paternidade, entre espírito e natureza. Na presente ocasião, e de acordo com os nossos objectivos, acompanharemos o modo como Antero perspectiva a possibilidade dessa síntese, porém apenas no que nela é relevante para uma filosofia da natureza. Nesse sentido, limitaremos a nossa análise à exposição das bases para um espiritualismo renovado, capaz de responder às críticas originárias quer das tendências materialistas quer das tendências cépticas, pela superação do velho espiritualismo «mitológico» francês. $\mathrm{O}$ instrumento pelo qual Antero dá conta da passagem do velho ao renovado espiritualismo é o criticismo ou, mais precisamente, o neokantismo, por vezes associados à nova psicologia.

28 É esse o juízo que António Sérgio formula nas suas Notas sobre os «Sonetos» e as «Tendências Gerais da Filosofia» de Antero de Quental (1909) - "Quem lê os dois primeiros capitulos das Tendências gerais da filosofia na segunda metade do séc. XIX sente-se arrastado por uma certa fluidez vaga, onde é difícil encontrar uma sequência lógica precisa, apesar da clareza aparente devida à sua prosa tão bela, ainda que talvez muito igualmente iluminada. Depois de atacar, na segunda parte, as grandes construções especulativas e os seus «mitos» em nome das «ciências modernas», da «observação», da «adaptação aos factos», da «indução cautelosa», Antero na terceira levanta repentinamente um palácio de ideias escandalosamente aéreo e poético, ressuscitando a "pretensão exorbitante» que pouco antes atacara: terramoto de cenário, que num pronto se refaz. (...) quando se não tem muito método, rigor científico, espírito crítico e objectivo, é infalível que sejam precisamente os sentimentos quem governe nos sistemas (...)». (Op. cit., p. 221).

29 Aliás, esta segunda tese fora já intuída, de modo bastante esquemático, em $O$ Futuro da Música, 1866, como bem indica Leonel Ribeiro dos Santos ao citar a seguinte passagem do artigo de Antero: «Não creio que o positivismo um tanto estreito de A. Comte, Littré e da última escola francesa, nos dê completa a filosofia do futuro. Mas se o alargarmos, seguno o espírito hegeliano, a ponto de caber nele a metafísica excluída por A. Comte (...) nesse caso tenho para mim que a filosofia assentará numa base tão sólida, que não será muito aventurar dizer que está achada e definitivamente constituída a filosofia do futuro». (SANTOS, L. R., Apresentação in Quental, Antero, Tendências Gerais da Filosofia na Segunda Metade do Século XIX, Editorial Comunicação, 1989, Lisboa, p. 17). 
O espiritualismo, assim renovado, não apenas se defende do materialismo e do cepticismo, tendências que não subsistem por elas próprias, como vem revestir os pontos capitais, no entretanto já estabelecidos, da própria filosofia anteriana. Comecemos por ver, de acordo com o texto, como se defende o espiritualismo:

«Ao cepticismo opõe a nova doutrina espiritualista o testemunho da consciência, e não precisa de mais. Ao materialismo opõe a impossibilidade racional de fazer sair da matéria, não se diz já uma ideia ou uma volição, mas o facto de consciência mais elementar, uma simples sensação» ${ }^{30}$.

Contra o cepticismo o espiritualismo agora professado apresenta o "testemunho da consciência", justamente o testemunho daquilo a que, já em Filosofia da Natureza dos Naturalistas, Antero chamava "o facto positivo culminante" ou o "critério filosófico": a consciência humana ${ }^{31}$. Por seu lado, o materialismo, entendido como o sistema que reduz toda a realidade a matéria, quer dizer, a movimento e a extensão, não é, segundo o autor, capaz de se assegurar do seu próprio ponto de partida, deixando por explicar o que seja a sensação.

Feita esta apologia do novo espiritualismo face a outras tendências filosóficas, é precisamente pelo excesso da mais simples sensação relativamente ao materialismo que Antero de Quental vai poder apontar os limites inerentes ao mecanicismo, pois o que de excessivo, relativamente à matéria, há nos seres é justamente o que permite explicar aquilo que o mecanismo somente consegue descrever ${ }^{32}$. Enquanto que o mecanismo faz o relato do abstracto, do manifesto e do superficial, só a consciência, que se conhece por si própria, pode conhecer, afirma Antero de Quental, "isso que a mecânica ignora as verdadeiras causas, o ser íntimo e a realidade substancial das coisas" ${ }^{\prime 33}$.

A consciência, como força activa espontânea, conhece-se a si própria e só se afigura como misteriosa se for percepcionada de fora. Tomada como "facto culminante", tal como se pôde verificar em Filosofia da Natureza dos Naturalistas, a consciência é o verdadeiro ponto de partida de uma filosofia que se queira sintética. E esta assunção da consciência como força, a um tempo, espontânea e capaz de testemunho - que lhe confere o estatuto de força-tipo -, é a tese nuclear do novo espiritualismo adoptado por Antero e que, afirma ele, se resolve num "dinamismo psíquico" em contraste com a ideia, professada pelo materialismo mecanicista e abstracto, de um "dinamismo mecânico":

«Assim pois, segundo o nosso espiritualismo, o espírito define-se como uma força autónoma, que se conhece na sua íntima natureza, que é causa

Quental, Obras Completas. Filosofia, p. 152.

«Os factos da consciência humana são pois não só factos positivos, mas os factos positivos culminantes. (...) A consciência humana é pois verdadeiramente um critério filosófico, neste sentido, que uma filosofia incapaz de explicar satisfatoriamente os fenómenos da consciência, ou em contradição com eles, é uma filosofia incompleta, ou errada, por deixar de fora, ou contradizer, uma parte e justamente a parte mais importante da realidade». (Op. cit., p. 109) «A intensidade, a direcção $\mathrm{e} o$ encadeamento das forças que num dado momento actuam no universo, eis tudo quanto o mecanismo sabe, ou antes, quanto pode aspirar a saber. (...) Porque caiu esta pedra? Porque a sua energia passou do estado potencial ao de força viva. E porque passou? Porque uma energia maior actuou sobre ela, desmanchando o equilíbrio anterior. Mas que relação de verdadeira causalidade há entre um facto e outro?...». (Op. cit., p. 153) Para logo se concluir que o mecanismo «conhece a mecânica dos movimentos, mas não a causa do movimento, conhece as aç̧ões dos seres, mas não a actividade interna que as produz. Conhece o universo como série de factos abstractos, não como série de realidades verdadeiramente substanciais». (Op. cit., ibidem).

Op. cit., p. 154. 
dos seus próprios factos e só às suas próprias leis obedece, que a essas leis submete os factos objectivos e só assim lhes dá significação e realidade, que a si mesma determina o seu próprio fim, que existe em si e em si encontra a sua plenitude. Sendo a força autónoma, consciente e plena, é a força por excelência, a força tipo. O espiritualismo resolve-se pois num dinamismo psíquico, assim como o materialismo da filosofia científica da natureza se resolvera num dinamismo mecânico» ${ }^{34}$.

Mas se há aspecto que na filosofia de Antero marca o seu idealismo é aquele que afirma precisamente que "o tipo é realizado na série, não é um produto dela", nos termos da Filosofia da Natureza dos Naturalistas, o que determina não só a anterioridade ontológica do tipo perfeito relativamente à série imperfeita com também a sua superioridade epistemológica. Por causa desta superioridade, Antero entende que as forças do mundo só podem ser compreendidas pelo seu tipo respectivo, a consciência. Esta deve, por conseguinte, constituir-se, relativamente à factualidade que dela emerge, como ponto de partida para uma indução filosófica. Essa afirmação peremptória da factualidade da consciência é que faz da filosofia de Antero de Quental um realismo sui generis, que, como vimos, apesar de conjugado com um determinado idealismo, dito espiritualista, recusa o idealismo dogmático alemão. Se este último acreditara poder deduzir especulativamente toda uma filosofia, aquele toma por imprescindivel que a especulação metafísica seja a forma que tome por conteúdo material as induções da factualidade; simplesmente, não qualquer uma, mas a da consciência ${ }^{35}$.

Uma filosofia assim formulada carece, como Antero bem vê, de dois pressupostos axiomáticos. Um primeiro que legitime logicamente a passagem do conhecimento que a consciência tem de si própria ao conhecimento do que lhe não é imanente, isto é, que certifique a indução filosófica. E um outro, prévio ao primeiro, que valide o conhecimento que a consciência adquire dela própria. A este, Antero de Quental liga o que denomina "problema da certeza", problema que se dissolve, a seu ver, na ideia de que o que é imediatamente evidente é necessariamente certo e válido, e que isso é o caso para o facto da consciência ${ }^{36}$. Ao pressuposto da passagem, com que se legitima o ganho cognitivo da indução filosófica (aquela que se constitui a partir da factualidade da consciência), Antero responde com a "identidade [hegeliana] do ser e do saber", pelo que a passagem da consciência às forças do mundo faz-se por terem algo de idêntico.

«Esta explicitação da essência oculta do mundo fenomenal pela essência do espírito, patente na consciência, é perfeitamente legítima. Não é uma generalização arbitrária, ou apenas mais ou menos plausivel, mas a forma rigorosa e completa do processo necessário de indução, que ressalta da mesma constituição do nosso entendimento. Pensar sobre o mundo é já supor nele alguma cousa de fundamentalmente análogo aos princípios da razão, é supô-lo racional. Ora, esta suposição implica a da identidade fundamental do objecto e do sujeitor» ${ }^{37}$.

Op. cit., pp. 155-156.

E razoável encontrar nesta indução filosófica da factualidade da consciência um pressentimento do que virá a constituir no séc. XX a via fenomenológica da filosofia, pelo menos desta forma: os factos da consciência, i.e, revelados a partir de uma consciência que os vive, pode bem encontrar eco na noção husserliana de "vivência intencional".

"O "problema da certeza" não é propriamente problema, porque consiste em procurar a demonstração categórica dum facto primordial, que é indemonstrável no terreno da dialéctica, mas que na espontaneidade da consciência tem o carácter da evidência» (Op. cit., p. 157).

Op. cit., p. 156. 
Note-se, neste ponto, que a identidade hegeliana entre sujeito e objecto, longe de constituir um expediente ad hoc para assegurar o valor epistémico da indução filosófica, não faz mais do que reformular, assim contendo-a, a tese da irmandade da alma e do mundo, matriz de todo o pensamento anteriano, desde Espontaneidade. Se uma objecção é possível a esta indução filosófica no estrito âmbito dos argumentos de Antero de Quental, será a de um círculo porventura vicioso entre o que vale como tese e o que vale como justificação, pois seria justamente a irmandade, o elo de vida, entre a natureza e o espírito (ou entre o objecto e o sujeito) a tese a que a indução filosófica daria sustento. E no entanto, eis que Antero faz a autoridade de Hegel confirmar a tese, recolocando-a, qual petição de princípio, na posição de razão que justifique o passo indutivo de uma consciência do mundo. Assim, a interioridade do mundo tornar-se-ia evidência pela evidência da interioridade do espírito, resolvendo aquela nèsta, desiludindo a irmandade na simples relação entre uma imagem e o seu reflexo.

Podemos pois concluir que é por esta via que Antero de Quental pretende ter superado as divergências entre as principais correntes filosóficas do seu tempo, congregando-as num único sistema - a sintese entre o "realismo" de uma indução sobre factos, o "idealismo" da anterioridade ontológica dos tipos face às séries, o "espiritualismo" da preeminência da consciência como ponto de partida, e o "criticismo" da presença incontornável do testemunho vigilante da experiência. Esta síntese resulta num novo espiritualismo que se funda na natureza e se fundamenta na consciência, naturalizando esta e espiritualizando aquela. Simplesmente, a ambição, em Tendências, de resolver o paradoxo de uma interioridade da natureza arrisca a desaparição do próprio carácter de interioridade, seja o da natureza seja mesmo o do espírito. 